\title{
A lakókörnyezeti sajátosságok és a munkavállalási célú migrációs szándék kapcsolatának vizsgálata
}

\section{Analysis of relationship between living environment and labor migration potential}

\author{
BERÉNYI LÁSZLÓ
}

BERÉNYI László: egyetemi docens, Miskolci Egyetem, Vezetéstudományi Intézet; 3515 Miskolc-Egyetemváros; szvblaci@uni-miskolc.hu

KULCSSZAVAK: környezeti migráció; migrációs szándék; lakókörnyezet

ABSZTRAKT: A munkavállalási célú migrációs szándék mikroszintű vizsgálata során számos gazdasági, szociológiai és pszichológiai tényezővel kell dolgozni. A vizsgálati szempontok bővítése és újragondolása lehetőséget ad arra, hogy árnyaltabb képet alkossunk a migráció motivációiról. E tényezők között különös figyelmet kap a környezet kérdése, általában a katasztrófák és a klímaváltozás vándorlásra gyakorolt hatására fókuszálva. A környezetet tágabban értelmezve célszerủ a lakókörnyezet sajátosságainak bevonása a mikroszintű vizsgálatokba. A tanulmány a MOVE projekt kiegészítő pilotvizsgálatának eredményeit mutatja be a Miskolci Egyetem gazdálkodási szakjain tanuló hallgatók 184 elemű mintáján keresztül, arra keresve választ, hogy a jelenlegi és jövőben elképzelt lakókörnyezet mutat-e kapcsolatot az országhatáron belüli és azon túli munkavállalási célú migrációs szándékokkal. A kérdőíves felmérés eredményei a lakókörnyezeti tényezők és a migrációs szándék között kevés esetben mutatnak közvetlenül szignifikáns kapcsolatot. Ugyanakkor a munkavállalási célú migrációs szándék kapcsolatot mutat a lakókörnyezeti tényezők jövőbeli elvárásaival, továbbá a változtatási igényekkel, ezeket tehát célszerủ beépíteni a további, szélesebb körű empirikus felmérésekbe. Az eredmények arra is utalnak, hogy a lakókörnyezeti tényezőkkel elégedetlenek hajlandóbbak a migrációra. Külön vizsgálatokat igényel az a tapasztalat, hogy a tartós külföldi munkavállalásra kevésbé hajlandó válaszadók a rövid idejű kint tartózkodás lehetőségét vonzónak tartják.

László BERÉNYI: associate professor, Institute of Management Science, University of Miskolc; 3515 Miskolc-Egyetemváros, Hungary; szvblaci@uni-miskolc.hu

KEYWORDS: environmental migration; migration potential; living environment

ABSTRACT: One of the most important challenges, both on the macro and the personal levels, is to explore the reasons behind and factors influencing labor migration. The relevant literature agrees that pure economic interest or necessity is not sufficient to explain its causes or even migration potential and that we also should consider various social and psychological aspects, for instance, environmental issues. Studies on the subject consider the environmental mostly

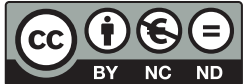


only in the form of disasters or as effects of climate change but there can be other interpretations. This paper focuses on the living environment (encompassing residential area and apartment type) as a valuable issue because, with migration, it surely goes through a fundamental transformation.

The paper summarizes the results of a pilot survey linked to the international MOVE project, executing systematic data collection in Borsod-Abaúj-Zemplén county about young people's mobility patterns. Research sample consists of 184 business students of the University of Miskolc and is not representative.

Responses about migration potential outlined five groups of migration intention. 15.2\% of the sample definitely plans labor migration even abroad or within Hungary, $4.9 \%$ surely reject the idea, $43.5 \%$ is open to labor migration within Hungary and $25.5 \%$ only abroad for a while. $10.9 \%$ is the ratio of uncertain respondents. Moreover, working abroad is mostly a short-term interest, as well as a Hungarian workplace with missions abroad. Respondents from cities are more open to labor migration than rural resident ones.

The survey also asks about present and expected future settlement, residential area and house or flat types. The core variables include intention to labor migration within Hungary or abroad. The analysis' main goal is to explore the relations between the variables in order to prepare a wide empirical survey. Its results show that while a convincing relationship is missing between the factors of present living environment and labor migration potential, the future expectations and the need to change the living environment or the house type show significant relations with it. Behind the need for change may stand dissatisfaction and, therefore, measuring satisfaction with the living environment would be useful if the impact of other factors could be filtered out. These experiences also allow us to formulate targeted questions.

\section{Bevezetés}

Az okok és motivációk feltárása a migráció makro- és mikroszintű vizsgálata során fontos feladatnak tekinthető. A szakirodalom a migráció típusainak meghatározásával jól lehatárolható okokat, pontosabban okcsoportokat jelöl meg, továbbá nagy az egyetértés abban, hogy a globalizáció a migráció egyik legfontosabb mozgatórugója (Lipták 2015). Geréb (2008) a munkaerő-migrációt a népességmozgás tipikus eseteként jelöli meg. A jelenségek célirányos kezeléséhez - és az aktuális gazdaságpolitikai célok eléréséhez - elengedhetetlen az egyéni motivációk megismerése is.

A migráció kutatása túllépett a jogi és közigazgatási kérdések szintjén, az egyéni képességek és készségek szerepe meghatározó a vizsgálatokban (Rédei 2007). Rudzitis (1991) rámutat arra, hogy a nem gazdasági tényezők szerepe növekszik a migrációs döntésekben: az időjárásnak, a szolgáltatások elérhetőségének, mennyiségi és minőségi jellemzoinek is meghatározó szerepük van. Nem lehet tehát egyértelműen gazdasági, vallási, politikai vagy éppen környezeti alapon megmagyarázni a migrációt, okok és hatások komplex rendszeréről van szó, amelyek tértől és időtől sem függetlenek.

Sik és Simonovits (2002) magyarországi háztartási panelvizsgálatok alapján arra az eredményre jutottak, hogy a lakosság 6\%-át kitevő elvándorlás várható, éltek azonban azzal a feltételezéssel, hogy a vándorlási szándékkal rendelke- 
zőknek csak egy töredéke hagyja el majd ténylegesen az országot. Kapitány és Rohr (2013) a 18-49 éves korosztályban 335 ezer före (7,4\%) becsüli a tartósan külföldön tartózkodók és 480 ezer före (10,6\%) az országon belül, de nem bejelentett lakcímükön vagy azok közelében élők létszámát.

Sik és Szeitl (2016) rámutat arra, hogy a magyarok migrációs potenciálja - a rövid és hosszú távú munkavállalást tekintve - az 1990-es és 2000-es években folyamatosan nőtt, majd a 2012-es csúcsérték (19\%) után a 2000-es évek közepének szintjére csökkent. A földrajzi és munkaerőpiaci mobilitás 2009-es felmérése (Directorate-General for Employment and Social Affairs 2009) alapján kimutatták, hogy a migrációs potenciál a magyarok körében magas (29\%), közöttük lényegesen alacsonyabb azok aránya, akik migrációs tapasztalattal rendelkeznek (6\%). A külföldön élő magyarok társadalmi összetételével kapcsolatos tendenciákról Blaskó és munkatársai (2014) összefoglalása alapján tudjuk, hogy:

- a migránsok körében a férfiak dominálnak,

- magas a 26 és 50 év közöttiek aránya,

- Németország és az Egyesült Királyság a legfontosabb célországok,

- a felsőfokú iskolai végzettségűek aránya magasabb.

Blaskó és Gödri (2016) elemzésükben a diplomás kivándorlók csökkenő tendenciájú, de határozott felülreprezentáltságát mutatták ki, és állították, hogy a diploma megszerzése előtt állók sajátosságainak megismerése elősegítheti az okok jobb megértését.

Pilot kutatásom mintájául a Miskolci Egyetemen gazdálkodási szakokon tanulmányokat folytató hallgatókat választottam. Ennek okai:

- a modern ipari fejlesztések és gyártelepítések során a mérnökök mellett sok szervezési, adminisztratív, projektmenedzsment és egyéb gazdálkodási feladatot ellátó, felsőfokú végzettségű szakemberre is szükség van,

- habár ezek a szakok hazánkban is keresett végzettséget kínálnak, a külföldi kereseti lehetőségek általában kedvezőbbek, továbbá

- különösen a multinacionális vállalatoknál „házon belül” is megjelenik a külföldi munkavállalás lehetősége, esetenként a más országba telepített termelőegységeknél szerzett tapasztalat az előrejutás feltétele.

Tanulmányomban a migráció okainak egy szűk területével, a migrációs szándék és a lakókörnyezeti háttér közötti összefüggések feltárásával foglalkozom. A kutatás feltevése, hogy a jelenlegi lakókörnyezetnek taszító hatása lehet, azaz a lakókörnyezethez kapcsolódó ismérvek és a munkavállalási célú migrációs szándék között kapcsolat van.

Egységes álláspontot mutatnak a kutatások abban a kérdésben, hogy a migrációs potenciál nem feltétlenül jár tényleges migrációval, a döntések mögött komplex egyéni és intézményi tényezők húzódnak (De Haas 2010; Massey et al. 1993). A népszerű vonzó-taszító és gravitációs elméletek feltételezik, hogy az emberek vándorolni fognak, ha a migráció előnyei meghaladják annak költségeit (De Haas 2014), a gyakorlatban azonban ilyen leegyszerüsítéssel nem célszerű élni. A kulturális háttér (Massey et al. 1993), a várakozások hatása, a 
forrás- és célterület centrum-periféria viszonya (Kincses, Rédei 2010), a személyes információ korlátozottsága, a vagyoni lehetőségek, a hazai és nemzetközi jogi szabályozás (Hautzinger 2016) csupán néhány a befolyásoló tényezők közül. Ezek mellett közvetett tényezőkkel is számolni kell. Lipták (2014) észak-magyarországi foglalkoztatási adatok elemzése alapján mutat rá, hogyan térítik el a külső gazdasági sokkhatások a munkaerőpiaci folyamatokat, amelyek előjelzését a gazdasági sokk késleltetett hatása is nehezíti. Érdekes és jelentős befolyásoló tényező továbbá a migrációban érintett ország(ok) geopolitikai helyzete. Rédei és Kincses (2008) kiemelik, hogy a globális, kontinenseken átívelő migrációban Magyarország közvetítő módon tud részt venni.

A szakmák szerint bontott vizsgálatok megerősítik, hogy a receptszerü megoldások érvényessége korlátozott. Különös figyelmet kapnak például az egészségügyi dolgozók (Eke, Girasek, Szócska 2009; Pitó 2015). Ezek a kutatások azt állítják, hogy az intézkedések hosszú távú hatásait egyrészt nehéz megbecsülni, másrészt a szakmák és az intézményrendszer sajátosságai miatt nem lehet általánosítani. Az induktív következtetéseknek számos részkérdést vizsgáló elemzésen kell alapulnia.

A MOVE projekt kiegészítő pilotkutatásában a felsőoktatási hallgatók munkavállalási célú hazai és külföldi migrációs szándékát vizsgálom. A projekt - interdiszciplináris és többszintű kutatási megközelítést alkalmazva - azt kutatja, hogyan lehet a fiatalok mobilitása ,jó" a társadalmi-gazdasági fejlödés szempontjából és a fiatalok egyéni fejlődésében, melyek a segítő és gátló tényezők (DabasiHalász 2015). Figyelembe véve a migrációs folyamatokat magyarázó tényezők sokféleségét és komplexitását, különösen az egységes modellalkotás nehézségeit (De Haas 2014), fontosnak tartom az útkereső empirikus vizsgálatokat.

\section{A munkavállalási célú migráció hazai kutatásának egyes eredményei}

A munkavállalási célú migráció kérdésével empirikus kutatások széles köre foglalkozik (Bodnár, Szabó 2014; Hárs 2011; Hárs, Simon 2015). A Legújabb trendek a magyarországi kivándorlásban című OTKA-projekt területileg vizsgálta a magyarországi migráció helyzetét és a népesség migrációs szándékát. A nagymintás vizsgálat a 30 év alattiak 58,2\%-ánál mutatta ki, hogy nem tervezi jövőjét Magyarországon, ez a szándék az életkor emelkedésével csökken, a 41-44 éves korosztálynak már csak 20,8\%-a gondolja így. Nógrád és Heves megyében a legmagasabb a kivándorlást tervezők aránya. Heves megyében például 17,1\% fölött van a kivándorlást tervezők, de $1 \%$ alatt a kivándoroltak aránya, míg BorsodAbaúj-Zemplén megye a 14,1-17\%-os kategóriába tartozik a kivándorlást tervezők, de az 1,1-2\%-os kategóriába a kivándoroltak arányát tekintve (Kóródi, Siskáné Szilasi 2016). 
Az Észak-magyarországi régió, elsősorban Borsod-Abaúj-Zemplén megye és Miskolc migrációs kérdéseivel foglalkozik részletesen a MOVE projekt (Dabasi-Halász 2015). A kutatás szisztematikus adatgyűjtés segítségével rajzolta meg a fiatalok mobilitási mintáit Európában. Dabasi-Halász és Hegyi-Kéri (2015) kiemelik, hogy a fiatalok mobilitási mintái változatosak, azt nem lehet leegyszerűsíteni csupán tanulási célú és munkavállalási migrációra. A munkaerőpiaci életutak gyengülését tárták fel azzal összefüggésben, hogy a „felnőtté válás” egyre inkább kitolódik a fiatalok életében.

Tanulási - nem munkavállalási - célú migrációval foglalkozik a felsőoktatásban tanulók körében Honvári (2012). A felsőoktatási mintában szereplők 68\%a gondolkozott egy évnél rövidebb külföldi tanulmányokban, 37\%-a egy évnél hosszabban. A kutatás a nyelvtudás szintje és a külföldi tanulási szándék között csak gyenge kapcsolatot mutatott ki. Kérdőíves felmérése alapján elsősorban nem a (szakmai) tanulási lehetőségek alapján választanak a hallgatók célországot, a nyelvtanulás lehetősége, az ismerősök ajánlásai, a rendelkezésre álló kapcsolati háló jobban befolyásolja döntésüket. A tanulás finanszírozásában elsősorban a család támogatása dominál, nem jellemző a diákok munkavállalása.

\section{A környezeti migráció értelmezésének kiterjesztése}

A migráció motivációi között fontos a környezet kérdése (Hautzinger, Hegedüs, Klenner 2014). A környezet általában a kényszerü migrációt kiváltó okként (Dun, Gemenne 2008) jelenik meg a szakirodalomban, katasztrófák vagy klímaváltozás formájában (Marino 2012; Reuveny 2007; Vág 2010). Black (1998) kiemeli, hogy kifejezetten környezeti migránsok (menekültek) nem léteznek, a környezeti változásokhoz kapcsolódó migrációban politikai és gazdasági tényezők is szerepet játszanak.

Tanulmányomban a környezet egy szúkebb területével, a lakókörnyezettel foglalkozom, beleértve a település, a lakás vagy ház típusát és a lakókörnyezet jellegét. Mivel a migráció során a lakókörnyezet bizonyos elemei az egyén számára megváltoznak, érdemes figyelmet fordítani annak vizsgálatára, hogy a migrációs folyamatokat hogyan befolyásolja a jelenlegi és a jövőbeli (elképzelt, elvárt) lakókörnyezet. A társadalmi mobilitást középpontba helyezve és a területi hatásokat is kimutatva, Földi (2000) végzett elemzést a lakókörnyezet és a mobilitás kapcsolatának feltárására Budapesten. Kutatásom ötletét Földi tanulmányának azon gondolata adta, hogy a lakókörnyezet minőségének makroszinten jelentkező és mérhető jellemzőit érdemes mikroszinten, az egyén szubjektív migrációs döntéshozatalában vizsgálni. Munkámban ugyanakkor a (lakó)környezetre nem mint a vizsgálat közvetlen tárgyára, hanem mint csoportképző ismérvére tekintek, és arra keresek választ, hogy az a migrációs szándékkal kapcsolatban áll-e. 


\section{A vizsgálati módszer}

A felmérés önkitöltő, anonim, elektronikus kérdőívet használt. Az adatgyüjtést a Miskolci Egyetem Evasys rendszerében, a feldolgozást az IBM SPSS Statistics Version 22-vel végeztem. A kérdőív a hazai és nemzetközi munkavállalási célú migráció szándékát, célterületeit, okait vizsgálta. A lakókörnyezet és a migrációs szándék közötti kapcsolat vizsgálatához a kérdőív külön blokkokat tartalmazott a jelenlegi és jövőben vágyott településtípusra, a ház vagy lakás típusára (egyéni, társas), a lakókörnyezet típusára (belváros, kertváros, lakótelep, nem városi családi házas környezet, tanyasi környezet, egyéb). A kapcsolatok vizsgálatához kereszttábla-elemzést használtam, a kapcsolatok létét a Pearson-féle $\chi^{2}$ mutató szignifikanciájának vizsgálata alapján állapítottam meg (95\%-os megbízhatósági szinten). Az elemzéseket több csoportképző szempont szerint végeztem el, amelyek teljes bemutatása túlmutat e tanulmány keretein.

\section{A minta összetétele}

A kutatás adatgyűjtési szakaszára 2017 februárjában és márciusában került sor. Az elemzéshez 184 fös minta állt rendelkezésre a Miskolci Egyetem gazdálkodási tanulmányokat folytató hallgatóinak válaszaiból. A minta reprezentativitása nem ellenőrzött, a megállapítások a mintára érvényesek, céljuk további kutatási feladatok előkészítése.

A 184 válaszadó 32,1\%-a alap-, 67,9\%-a mesterszakon folytatja tanulmányait; 51,4\% nappali, 48,6\% levelező tagozaton. A válaszadók közül 130 fö (70,7\%) nö, 54 fö $(29,3 \%)$ férfi.

A válaszadók 65,8\%-a ma is a szülői házban él, a szülői házat elhagyók aránya a nappali tagozatosok között 10,6\%, a levelező tagozatosok között 58,8\%. Az okok közül a saját család alapítása dominál (47,6\%), egyedül élni 17,5\%-uk szeretne. A válaszadók 54,9\%-a egyedi építésű házban, 10,4 \%-a néhány lakásos társasházban vagy sorházban, 31\%-uk nagyobb (lakótelepi) társasházban nőtt fel.

Saját bevallása szerint nagyvárosban nőtt fel a válaszadók 39,7\%-a, kisvárosban 33,7\%-a és községben 26,6\%-a. 10-15 év múlva a válaszadók 62\%-a képzeli el életét nagyvárosban, 28,8\%-uk kisvárosban és 9,2\%-uk községben. A kisvárosban felnövők 45,2\%-a, illetve a községben élők 40,8\%-a költözne nagyvárosba, míg az ott felnövőknek 8,2\%-a költözne kisvárosba és 1,4\%-a községbe. A nagyvárosban maradni akarók aránya az ott élők 90,4\%-a.

A lakás környezetét tekintve a kertváros a legvonzóbb célterület (63,6\%), ezt a belváros $(15,2 \%)$ és a nem városi, családi házas környezet követi (14,1\%). Lakótelepen 4,3\% képzeli el életét. A válaszadók egyértelműen önállóságra vágynak, 70,1\%-uk egyedi építésű házat jelölt meg elképzelt lakóhelyként, tégla- vagy panelépítésű, több emeletes társasházat mindössze 10,9\%-uk. A nem 
kertvárosban felnövő 133 fö válaszadó közül 73 (54,8\%-uk) költözne kertvárosba. Belvárosba 9,2\%-uk, lakótelepi lakásba 4,8\%-uk, nem városi családi házas környezetbe 4,7\%-uk vágyik.

A válaszadók 58,7\%-a Magyarország távolabbi területeire is elköltözne, 10,3\%-a maradna, 31\%-a pedig bizonytalan. A költözés melletti érvük egyértelműen a bér- és jövedelemszerzés, a karrier, illetve a jobb életkörülmények elérése. A barátok és ismerősök tapasztalatai támogató hatásúak, a válaszok 67,8\%-ában ezek a költözés mellett szóló érvként jelennek meg. Ellene szól a kapcsolattartás lehetőségének korlátozottsága a családdal és az ismerősökkel.

Tartós külföldi munkavállalást a válaszadók $15,2 \%$-a tervez, rövid idejüt azonban 38\% tart elképzelhetőnek. Biztosan nem vállalna munkát külföldön $8,2 \%$, bizonytalan a kérdésben $20,7 \% .17,9 \%$ a hazai munkát külföldi utazásokkal tartja elképzelhetőnek. A külföldi munkavállalás melletti és elleni érvek a hazai költözéshez hasonló mintát mutatnak.

A hazai és külföldi munkavállalási célú migrációra való hajlandóság között az elemzés szignifikáns kapcsolatot mutatott ki. Azok között, akik országon belül elköltöznének, $25,9 \%$ tartós külföldi munkát is vállalna. Az országon belüli migrációt nem tervezők 31,6\%-a rövidebb ideig külföldön is dolgozna, sőt a bizonytalanok $42,1 \%$-a is igen választ adott erre a kérdésre. A külföldi munkavállalási szándék tervezett időtartamát figyelembe véve $\left(\chi^{2}=54,897, d_{f}=8\right.$, sig $=0,000)$ és kiszürve $\left(\chi^{2}=30,065, \mathrm{~d}_{\mathrm{f}}=4\right.$, sig=0,000) (1. táblázat) szignifikáns összefüggés mutatható ki a hazai és a külföldi munkavállalási célú migrációs szándék között. Azok körében, akik bizonytalanok a hazai migrációval kapcsolatban, 42,1\% a külföldi munkát vállalni szándékozók aránya, azonban ezt csak rövid időre vállalnák.

1. táblázat: A hazai és külföldi munkavállalási célú migrációs szándék kereszttábla-elemzése Cross tabulation analysis of domestic and foreign migration potential

\begin{tabular}{|c|c|c|c|c|c|c|}
\hline & & & \multicolumn{3}{|c|}{ (B) Vállalna-e külföldön munkát? } & \multirow[t]{2}{*}{ Összesen } \\
\hline & & & Igen & $\mathrm{Nem}$ & Nem tudom & \\
\hline (A) & Igen & Fő & 68 & 22 & 18 & 108 \\
\hline Munkavállalási & & $\%(\mathrm{~A})$ & $63,0 \%$ & $20,4 \%$ & $16,7 \%$ & $100,0 \%$ \\
\hline céllal (tartósan) & & $\%(\mathrm{~B})$ & $69,4 \%$ & $45,8 \%$ & $47,4 \%$ & $58,7 \%$ \\
\hline elköltözne & $\mathrm{Nem}$ & Fő & 6 & 13 & 0 & 19 \\
\hline Magyarország & & $\%(\mathrm{~A})$ & $31,6 \%$ & $68,4 \%$ & $0,0 \%$ & $100,0 \%$ \\
\hline távolabbi & & $\%(\mathrm{~B})$ & $6,1 \%$ & $27,1 \%$ & $0,0 \%$ & $10,3 \%$ \\
\hline \multirow[t]{3}{*}{ területeire? } & Talán & Fö & 24 & 13 & 20 & 57 \\
\hline & & $\%(\mathrm{~A})$ & $42,1 \%$ & $22,8 \%$ & $35,1 \%$ & $100,0 \%$ \\
\hline & & $\%(\mathrm{~B})$ & $24,5 \%$ & $27,1 \%$ & $52,6 \%$ & $31,0 \%$ \\
\hline \multirow[t]{3}{*}{ Összesen } & & Fő & 98 & 48 & 38 & 184 \\
\hline & & $\%(\mathrm{~A})$ & $53,3 \%$ & $26,1 \%$ & $20,7 \%$ & $100,0 \%$ \\
\hline & & $\%$ (B) & $100,0 \%$ & $100,0 \%$ & $100,0 \%$ & $100,0 \%$ \\
\hline
\end{tabular}




\section{A munkavállalási célú migrációs szándék motivációi}

A hazai és külföldi munkavállalási szándék kombinációi alapján csoportokat képeztem:

- határozott migrációs szándékúak: akik akár Magyarország távolabbi területein, akár külföldön tartósan vállalnának munkát;

- Magyarországhoz kötődők: Magyarország távolabbi területein igen, de külföldön nem vagy csak rövidebb ideig vállalnának munkát, illetve ebben bizonytalanok;

- külföldre vágyók: Magyarország távolabbi területein nem vagy talán, külföldön viszont vállalnának munkát (a mintában szereplő válaszadók tartósan nem vállalnának külföldön munkát);

- migrációt nem tervezők: Magyarország távolabbi területein nem vagy talán, előbbiek körében a külföldi munkavállalás kérdésében is bizonytalanok;

- bizonytalanok: mind a hazai, mind a külföldi munkavállalási célú migráció kérdésében bizonytalanok.

A részminták általános jellemzőit a 2. táblázat foglalja össze.

Határozott migrációs szándékúak. A magasabb jövedelemhez jutás igénye és a jobb életkörülmények biztosítása egyértelműen jellemzi a részmintát. A válaszadók 78,6\%-a szerint a karrierlehetőség egyértelműen a magyarországi költözés mellett szóló érv. A családdal és ismerősökkel való kapcsolattartás egyaránt a válaszadók 53,6\%-a szerint inkább a költözés mellett szól. Külföldi relációban 39,3\%-uk jelölte meg a családot mint a költözés mellett szóló érvet. A minta 64,3\%-a a külföldi munkavállalásban kalandot is keres. A célország kultúrája a válaszadók 75\%-a szerint a külföldi munkavállalás mellett szól.

Magyarországhoz kötődők. A magasabb jövedelemhez jutás, a jobb életkörülmények biztosítása és a karrierlehetőség e részmintában is jellemzően az országon belüli költözés mellett szól. A családi és baráti kapcsolatok ápolása inkább a költözés ellen szól: magyarországi költözés esetében a válaszadók 67,5\%-a jelölte meg a családot és $68,8 \%$-a a barátokat, ismerősöket, míg külföldi relációban

2. táblázat: Migrációs szándék szerint képzett csoportok jellemzői Characteristics of groups formed by migration potential

\begin{tabular}{|c|c|c|c|c|c|c|}
\hline \multicolumn{2}{|c|}{ Ismérvek } & \multirow{2}{*}{$\begin{array}{c}\text { Határozott } \\
\text { migrációs szándék }\end{array}$} & \multirow{2}{*}{$\begin{array}{c}\begin{array}{c}\text { Magyarországhoz } \\
\text { kötődók }\end{array} \\
80\end{array}$} & \multirow{2}{*}{$\begin{array}{c}\begin{array}{c}\text { Külföldre } \\
\text { vágyók }\end{array} \\
47\end{array}$} & \multirow{2}{*}{ 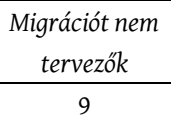 } & \multirow{2}{*}{$\begin{array}{c}\text { Bizonytalanok } \\
20\end{array}$} \\
\hline $\mathrm{N}\left(\mathrm{fog}^{\prime \prime}\right)$ & & & & & & \\
\hline \multirow[t]{2}{*}{ Nem } & Nő & $64,3 \%$ & $66,3 \%$ & $74,5 \%$ & $88,9 \%$ & $80,0 \%$ \\
\hline & Férfi & $35,7 \%$ & $33,8 \%$ & $25,5 \%$ & $11,1 \%$ & $20,0 \%$ \\
\hline \multirow[t]{2}{*}{ Szak } & Alap & $35,7 \%$ & $31,3 \%$ & $21,3 \%$ & $33,3 \%$ & $55,0 \%$ \\
\hline & Mester & $64,3 \%$ & $68,8 \%$ & $78,7 \%$ & $66,7 \%$ & $45,0 \%$ \\
\hline \multirow[t]{2}{*}{ Tagozat } & Nappali & $67,9 \%$ & $46,3 \%$ & $51,1 \%$ & $33,3 \%$ & $55,0 \%$ \\
\hline & Levelező & $32,1 \%$ & $53,8 \%$ & $48,9 \%$ & $66,7 \%$ & $45,0 \%$ \\
\hline
\end{tabular}

Megjegyzés: adatok a részminta \%-ában. 
73,8\%-a mindkettőt a nem oldalon. A kaland, kihívás keresésében Magyarországon a részminta $60 \%$-a, külföldön 72,3\%-a lát a költözés mellett szóló érvet. A célország kultúrája a válaszadók 70\%-a esetében a külföldi munkavállalást ösztönzi.

Külföldre vágyók. A jobb jövedelem elérésében nagyon erős motivációs lehetőséget látnak, 85\%-uk a karrierlehetőséget is a migráció melletti érvként ítéli meg. A kapcsolattartás a családdal (hazai és külföldi relációban egyaránt 75\%) és a barátokkal (hazai relációban 75\%, külföldiben 83\%) ugyanakkor egyértelműen a költözés ellen szóló érv. A kalandot a válaszadók körülbelül fele ítéli meg a migráció melletti és fele az elleni érvként.

Migrációt nem tervezók. A jövedelem, életkörülmények és karrier tekintetében egyértelműen kedvező lehetőséget látnak a migrációban, azonban 88,8\%-uk a családi és baráti kapcsolattartást meghatározó ellenérvként ítéli meg. A külföldi migráció kapcsán 44,5\%-uk jelölte meg, hogy a célország kultúrája a költözést nem ösztönzi.

Bizonytalanok. A jövedelem, életkörülmények és karrier tekintetében egyértelműen kedvező lehetőséget látnak a migrációban. A többi tényezőben körülbelül fele-fele arányban oszlanak meg a vélemények.

A fenti csoportosítás ismérveinek szignifikanciáját a 3. táblázat mutatja be. A magyarországi migrációra vonatkozó kérdésre (Munkavállalási céllal - tartósan - elköltözne Magyarország távolabbi területeire?) igen, nem és talán válaszokat adhattak a megkérdezettek, míg a tényezők megítélésénél arról kellett dönteniük négyfokozatú skálán, hogy az a döntés ellen szól, inkább ellene szól, inkább mellette szól, vagy mellette szól.

3. táblázat: A migrációs potenciál és a migrációt befolyásoló tényezők közötti kapcsolatok szignifikancia vizsgálata

Significant relations between migration potential and influencing factors of migration

\begin{tabular}{lccc}
\hline \multicolumn{1}{c}{ Ismérvek } & $\chi^{2}$ & $d_{f}$ & sig. \\
\hline Magyarországi migráció, bér és jövedelemszerzés & 29,473 & 12 & $0,003^{*}$ \\
Magyarországi migráció, a célterület híre & 26,337 & 16 & $0,049^{*}$ \\
Magyarországi migráció, karrierlehetőség & 46,462 & 16 & $0,000^{*}$ \\
Magyarországi migráció, kaland & 28,571 & 16 & $0,027^{*}$ \\
Külföldi migráció, a célország kultúrája & 49,813 & 16 & $0,000^{*}$ \\
Külföldi migráció, a kapcsolattartás barátokkal, ismerősökkel & 30,322 & 16 & $0,016^{*}$ \\
Magyarországi migráció, kaland & 36,734 & 16 & $0,002^{*}$ \\
\hline
\end{tabular}

\section{A lakókörnyezet és a munkavállalási célú migrációs szándék kapcsolata}

Kutatásom központi kérdése, hogy a különböző lakóhelyről és lakókörnyezetből érkező hallgatók munkavállalási célú migrációjának szándéka között kimutat- 
4. táblázat: A jelenlegi lakókörnyezeti tényezők és a munkavállalási célú migráció közötti kapcsolat szignifikanciavizsgálata

Significance test of the current living environment and the labor migration potential

\begin{tabular}{lccc}
\hline \multicolumn{1}{c}{ Ismérvek } & $\chi^{2}$ & $d_{f}$ & sig. \\
\hline Szülői ház településtípusa - országon belüli migrációs szándék & 3,959 & 4 & 0,412 \\
Szülői ház településtípusa - külföldi migrációs szándék & 4,147 & 8 & 0,844 \\
Szülöi ház lakókörnyezete - országon belüli migrációs szándék & 18,498 & 10 & $0,047^{*}$ \\
Szülői ház lakókörnyezete - külföldi migrációs szándék & 17,466 & 20 & 0,623 \\
\hline
\end{tabular}

ható-e kapcsolat. Ezen belül kereszttábla-elemzéssel vizsgáltam a hazai és külföldi munkavállalás kérdését is. A mintán belül a szülői ház településtípusának szignifikáns hatása nem mutatható ki (4. táblázat). A szignifikáns kapcsolatot mutató válaszok megoszlását az 1 . ábra mutatja be. Leginkább a kertvárosban élők nyitottak a migrációra (70,6\%), míg legkevésbé a nem városi családi házas környezetben élők (46,4\%), ugyanakkor közöttük a legmagasabb a bizonytalanok aránya is $(41,1 \%)$.

Hasonló vizsgálatot végeztem el a jövőben elképzelt településtípus és lakókörnyezet, illetve a migrációs szándék között. Szignifikáns kapcsolat van aközött, hogy 10-15 év múlva nagyvárosban, kisvárosban vagy községben képzeli-e el a válaszadó az életét, illetve munkavállalási céllal elköltözne-e Magyarország távolabbi területeire. A külföldi munkavállalási szándék esetén ilyen kapcsolat nem volt kimutatható. A lakókörnyezet típusa és a munkavállalási célú migrációs szándék között szintén csak hazai relációban mutatható ki szigni-

1. ábra: A Magyarországon belüli migrációs szándék a jelenlegi lakókörnyezet szerint (fó) Migration potential within Hungary by the living environment (persons)

0\% 10\% 20\% 30\% 40\% 50\% 60\% 70\% 80\% 90\% 100\%

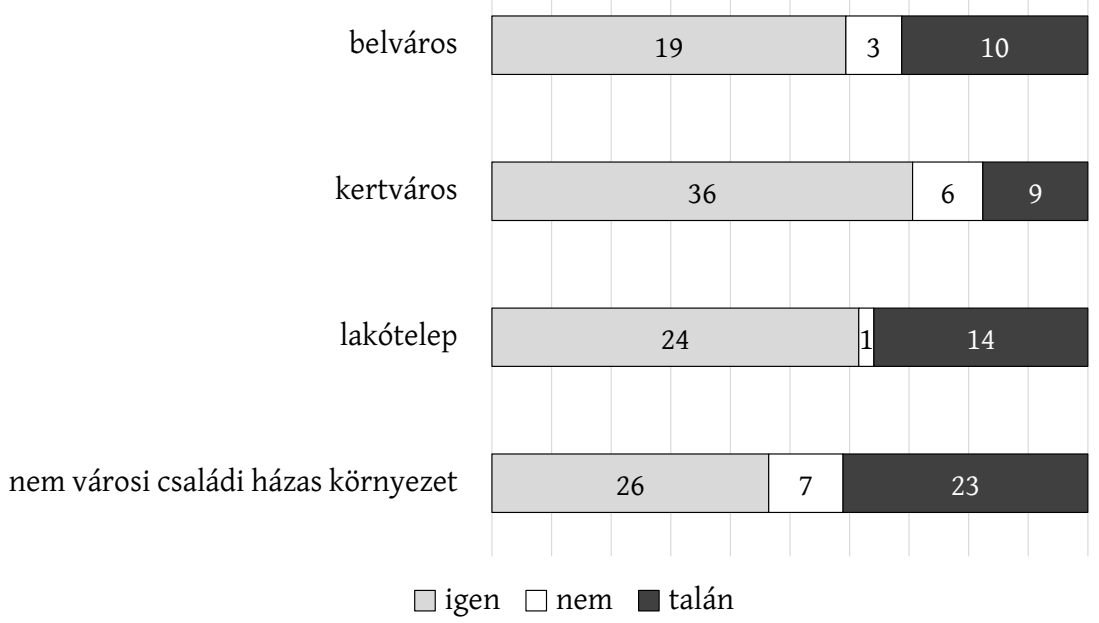


5. táblázat: Jövőben elképzelt lakókörnyezeti tényezők és munkavállalási célú migráció közötti kapcsolat szignifikanciavizsgálata

Significance test of the expected future living environment and the labor migration potential

\begin{tabular}{lrrc}
\hline \multicolumn{1}{c}{ Ismérvek } & \multicolumn{1}{c}{$\chi^{2}$} & \multicolumn{1}{c}{$d_{f}$} & \multicolumn{1}{c}{ sig. } \\
\hline Jövőben elképzelt településtípus - országon belüli migrációs szándék & 11,163 & 4 & $0,025^{*}$ \\
Jövőben elképzelt településtípus - külföldi migrációs szándék & 6,209 & 8 & 0,624 \\
Jövőben elképzelt lakókörnyezet - országon belüli migrációs szándék & 10,182 & 10 & 0,433 \\
Jövőben elképzelt lakókörnyezet - országon belüli migrációs szándék & 16,674 & 20 & 0,674 \\
\hline
\end{tabular}

fikáns kapcsolat (5. táblázat). A szignifikáns kapcsolatot mutató válaszok megoszlását a 2. ábra mutatja be. A nagyvárosba vágyók nyitottak leginkább a migrációra (66,7\%), legkevésbé pedig a községbe vágyók (29,4\%), azonban itt a legmagasabb a bizonytalanok aránya $(47,1 \%)$.

Elemzéseket végeztem arra vonatkozóan, hogy a jelenlegi és a jövőben elképzelt településtípus együttes figyelembevételével kimutatható-e különbség a migrációs szándékban. A nagyvárosban maradni kívánók 63,6\%-a országon belül költözne, ez az arány a nagyvárosba vágyók körében 70,8\%, a nagyvárosból elvágyók körében pedig 71,9\%. Horváth Gyula a szuburbanizációs folyamatok felgyorsulásaként fogalmazta meg ezt a folyamatot: a fóvárosok és egyéb centrumok kedvező munkalehetőséget, szolgáltatásokat, jobb életminőséget kínálnak, így a migráció egyre határozottabb célpontjává válnak (Rechnitzer 2016). A vidéken maradni vágyóknak 42,9\%-a költözne, ugyanakkor ebben a körben a legnagyobb a bizonytalanok aránya (41,3\%). Az eredmény 95\%-os megbízható-

2. ábra: A Magyarországon belüli migrációs szándék a jövőben elképzelt lakóhely településtípusai szerint (fö)

Migration potential within Hungary by the settlement type expected in the future (persons)

$$
\begin{array}{lllllllllll}
0 \% & 10 \% & 20 \% & 30 \% & 40 \% & 50 \% & 60 \% & 70 \% & 80 \% & 90 \% & 100 \%
\end{array}
$$

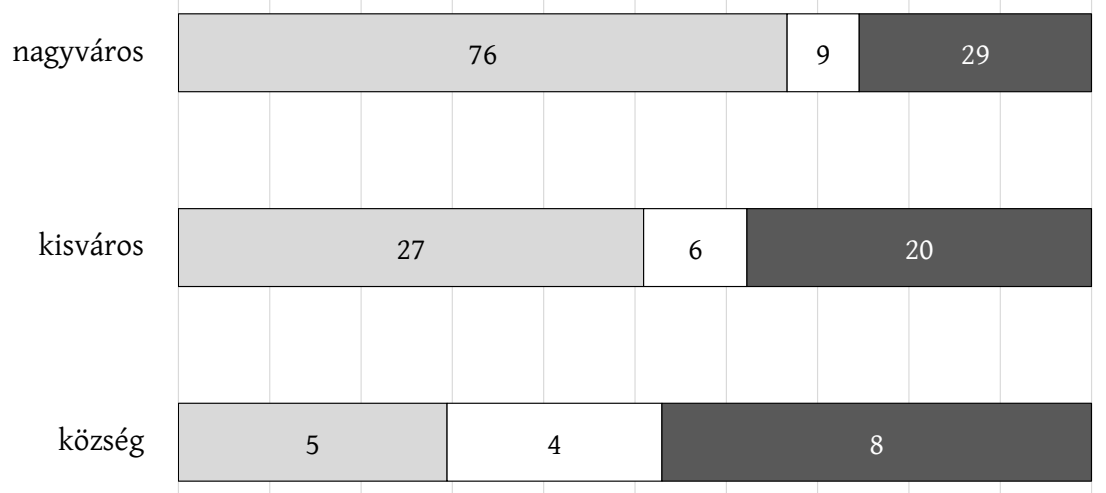

igen $\square$ nem $\square$ talán 
6. táblázat: Munkavállalási célú migrációs szándék és a lakás (ház) típusa közötti kapcsolat Relationship between labor migration and the type of the house (apartment)

\begin{tabular}{lccccccc}
\hline \multirow{2}{*}{ Ismérvek } & $N\left(f^{\prime \prime}\right)$ & \multicolumn{3}{c}{$\begin{array}{c}\text { Magyarországi munkavállalási célú } \\
\text { migrációs szándék }\end{array}$} & $\begin{array}{c}\text { Küldi munkavállalási célú migrációs } \\
\text { szándék }\end{array}$ \\
\cline { 2 - 8 } & & Igen & Nem & Bizonytalan & Igen & Nem & Bizonytalan \\
\hline Egyediben maradó & 83 & 48,2 & 16,9 & 34,9 & 55,4 & 25,3 & 19,3 \\
Egyedibe vágyó & 43 & 62,8 & 4,7 & 32,6 & 62,8 & 16,3 & 20,9 \\
Társasházban maradó & 33 & 72,7 & 3,0 & 24,2 & 45,5 & 39,4 & 15,2 \\
Társasházba vágyó & 18 & 77,8 & 0,0 & 22,2 & 44,4 & 22,2 & 33,3 \\
\hline
\end{tabular}

Megjegyzés: adatok a részminta \%-ában.

sági szinten nem szignifikáns $\left(\chi^{2}=11,497, \mathrm{~d}_{\mathrm{f}}=6\right.$, sig.=0,074). A külföldi munkavállalás kérdésében hasonló eredményeket mutatnak a kutatás részmintái: a nagyvárosból elvágyókat lehet kiemelni, akik között 14,3\% azok aránya, akik biztosan nem vállalnának külföldön munkát, míg 28,6\%-uk bizonytalan. Az eredmények nem szignifikánsak, a lakókörnyezet váltása vagy megtartása nem csoportképző ismérv.

Hasonló módon vizsgáltam az egyedi építésű és a társasházi környezet váltásának kapcsolatát a migrációs szándékkal. Szignifikáns kapcsolat a hazai migrációs szándékkal kapcsolatban kimutatható $\left(\chi^{2}=14,103, d_{\mathrm{f}}=6\right.$ sig $\left.=0,029\right)$. A válaszok megoszlását a 6 . táblázat foglalja össze.

Az elemzésbe bevonva a hazai és a külföldi munkavállalási célú migrációs szándék (igen, nem, bizonytalan) kombinációit is, szignifikáns kapcsolatot a jelenlegi lakókörnyezet $\left(\chi^{2}=50,345, \mathrm{~d}_{\mathrm{f}}=35\right.$, sig=0,045), a jövőben elképzelt lakástípus $\left(\chi^{2}=64,263, \mathrm{~d}_{\mathrm{f}}=42\right.$, sig=0,015) és a lakástípusváltás $\left(\chi^{2}=34,923, \mathrm{~d}_{\mathrm{f}}=21\right.$, sig=0,029) esetén találtam.

\section{Következtetések}

Black (1998) azon véleménye, miszerint a migráció csupán környezeti szempontokkal nem magyarázható, vizsgálataim alapján a lakókörnyezeti tényezőkel kapcsolatban is igaznak látszik. Az eredmények néhány tényező esetében ugyan mutatnak szignifikáns kapcsolatot, azonban ezt - a mintavétel korlátait is figyelembe véve - nem lehet általánosítani.

A válaszadók a magyarországi munkavállalási célú migráció elől nem zárkóznak el (legalábbis a szándék szintjén), de magas a bizonytalanok aránya. Külföldi munkát elsősorban rövid időre vállalnának, illetve népszerű a hazai munka lehetősége külföldi utazásokkal. A magasabb jövedelem szerzése és a karrier lehetősége a migráció melletti érvként, a családi és baráti kapcsolatok ápolása inkább a migráció elleni érvként jelenik meg a válaszadóknál. A lakókörnyezeti tényezők és a migrációs szándék között általában nincs szignifikáns kapcsolat. A nagyvárosba vágyók a leginkább nyitottabbak a magyarországi 
költözésre, a községbe vágyók a legkevésbé, viszont utóbbiak között kétszer akkora a bizonytalanok aránya, mint a nagyvárosba vágyók között. Szignifikáns különbség mutatkozik a szerint is, hogy a válaszadó belvárosban, kertvárosban, lakótelepen nőtt-e fel. A városi környezetben, különösen a kertvárosban felnövők nyitottabbak a migrációra, azonban az utóbbi csoportban a legmagasabb azok aránya, akik tartósan nem költöznének külföldre. A munkavállalási célú migrációs szándék hazai és külföldi kategóriáit kombinálva a lakástípust váltani kívánók között szignifikáns különbség mutatható ki.

A munkavállalási célú migrációs szándék a lakókörnyezeti tényezőkkel kapcsolatos jövőbeli elvárásokkal, továbbá a változtatási igényekkel mutat kapcsolatot. A változtatási igény mögött elégedetlenséget feltételezve a kutatás kiterjesztésének lehetőségét a relatív aspektusokban, a lakókörnyezettel való egyéni elégedettség vizsgálatában látom. További kutatásokat igényel a rövid idejü külföldi munkavállalásra nyitottak motivációi, különös tekintettel a határon átnyúló ingázásra mint a migráció speciális esetére (Hardi 2005; Hardi, Lampl 2008), amelyhez a kutatási minta kiterjesztésére van szükség. Hasonlóan érdekes információkat kaphatunk a Magyarországra érkező külföldi munkavállalók megkérdezésével, akik a tapasztalatok szerint sokszor idényjelleggel érkeznek, elsősorban Közép-Magyarországra (Hamar 2015).

\section{Irodalom}

Black, R. (1998): Refugees, environment and development. Longman, London

Blaskó Zs., Gödri I. (2016): A Magyarországról kivándorlók társadalmi és demográfiai összetétele. In: Blaskó Zs., Fazekas K. (szerk.): Munkaerőpiaci tükör 2015. MTA Közgazdaság- és Regionális Tudományi Kutatóközpont, Közgazdaság-tudományi Intézet, Budapest, 59-67.

Blaskó Zs., Ligeti A. S., Sik E. (2014): Magyarok külföldön - Mennyien? Kik? Hol? In: Kolosi T., Tóth I. Gy. (szerk.): Társadalmi Riport 2014. Tárki, Budapest, 351-372.

Bodnár K., Szabó L. T. (2014): A kivándorlás hatása a hazai munkaerőpiacra. Magyar Nemzeti Bank, Budapest (MNB-tanulmányok; 114.)

Dabasi-Halász Zs. (2015): Egy európai kutatás kezdetén: A MOVE projekt rövid bemutatása. ÉszakMagyarországi Stratégiai Füzetek, 1., 79-81.

Dabasi-Halász Zs., Hegyi-Kéri Á. (2015): „Fel/eltörekvő” generáció migrációja Miskolcon. Észak-Magyarországi Stratégiai Füzetek, 1., 17-26.

De Haas, H. (2010): The internal dynamics of migration processes: A theoretical inquiry. Journal of Ethnic and Migration Studies, 10., 1587-1617. http://doi.org/cpcs99

De Haas, H. (2014): Migration theory. Quo vadis? International Migration Institute, Oxford Department of International Development, University of Oxford. https://www.imi.ox.ac.uk/pdfs/wp/wp100-14.pdf (Letöltés: 2017. augusztus 22.)

Directorate-General for Employment and Social Affairs (2009): Geographical and labour market mobility. Brussels (Special Eurobarometer; 337.)

Dun, O., Gemenne, F. (2008). Defining 'environmental migration'. Forced Migration Review, October, 10-11.

Eke E., Girasek E., Szócska M. (2009): A migráció a magyar orvosok körében. Statisztikai Szemle, 7-8., 795-827. 
Földi Zs. (2000): A lakókörnyezet minőségének szerepe a főváros migrációs folyamataiban, az 1990-es években. Bevezetés a lakókörnyezeti lefelé és felfelé vándorlás elméletébe. Tér és Társadalom, 2-3., 219-228.

Geréb L. (2008): A regionális migráció hatása a humántőke-beruházásra és megtérülésre. Tér és Társadalom, 2., 169-184.

Hamar A. (2015): Külföldi idénymunkások a magyar agrárgazdaságban. Tér és Társadalom, 3., 33-48. http://doi.org/cdtp

Hardi T. (2005): Határon átnyúló ingázás, munkavállalás az osztrák-magyar határtérségben. Tér és Társadalom, 2., 65-82.

Hardi T., Lampl Zs. (2008): Határon átnyúló ingázás a szlovák-magyar határtérségben. Tér és Társadalom, 3., 109-126.

Hárs Á. (2011): Magyarok külföldi munkavállalása. Kopint-Tárki Zrt., Budapest

Hárs Á., Simon D. (2015): A munkaerö-migráció változása a kétezres években Magyarországon. Vizsgálat a munkaerö-felmérés adatai alapján. Budapesti Corvinus Egyetem, MTA KRTK KTI, Budapest (Budapesti Munkagazdaságtani Füzetek; BWP-2015/2.)

Hautzinger, Z. (2016): Szemelvények a migráció szabályozásáról. And Ann Kft., Pécs

Hautzinger, Z., Hegedüs J., Klenner Z. (2014): A migráció elmélete. Nemzeti Közszolgálati Egyetem Rendészettudományi Kar, Budapest

Honvári J. (2012): Migrációs potenciál és a potenciális tanulási migráció. Hazai hallgatók külföldi tanulási szándékai. Tér és Társadalom, 3., 93-113.

Kapitány B., Rohr A. (2013): A Magyarországon állandó lakcímmel rendelkező 18-49 éves magyar állampolgárok mintegy 7,4 százaléka tartózkodik jelenleg tartósan külföldön. Korfa, 3., 1-3.

Kincses Á., Rédei M. (2010): Centrum-periféria kérdések a nemzetközi migrációban. Tér és Társadalom, 4., 301-310.

Kóródi T., Siskáné Szilasi B. (2016): A XXI. századi magyar populáció migrációs szándékának térbeli vizsgálata. In: Berghauer S. (szerk.): Társadalomföldrajzi kihívások és adekvát válaszlehetőségek a XXI. század Kelet-Közép-Európájában. II. Rákóczi Ferenc Kárpátaljai Magyar Főiskola, Beregszász, 134-141.

Lipták K. (2014): Változó munkaerőpiac? Munkaerő-piaci előrejelzés Észak-Magyarországon. Területi Statisztika, 3., 220-236.

Lipták K. (2015): Foglalkoztatási lehetőségek a határon túl - avagy a migrációs folyamatok vizsgálata a kelet-közép-európai térben. DETUROPE: Central European Journal of Tourism and Regional Development, 7., 28-49.

Marino, E. (2012): The long history of environmental migration: Assessing vulnerability construction and obstacles to successful relocation in Shishmaref, Alaska. Environmental Change, 2., 374-381. http://doi.org/fgdf3s

Massey, D. S., Arango, J., Hugo, G., Kouaouci, A., Pellegrino, A., Taylor, J. E. (1993): Theories of international migration: a review and appraisal. Population and Development Review, 3. 431-466. http://doi.org/fpbvf4

Pitó K. (2015): „Nálunk (...) minden ötödik órában elhagyja az országot egy orvos”. Tér és Társadalom, 3., 93-114. http://doi.org/cdtq

Rechnitzer J. (2016): Elmozdulások és törésvonalak Kelet-Közép-Európa térszerkezetében. Tér és Társadalom, 4., 36-53. http://doi.org/cdtr

Rédei M. (2007): Mozgásban a világ. A nemzetközi migráció földrajza. ELTE Eötvös Kiadó, Budapest

Rédei M., Kincses Á. (2008): A szomszédból érkező migránsok hatása a hazai társadalmi és gazdasági különbségekre. Közép-Európai Közlemények, 1., 7-16.

Reuveny, R. (2007): Climate change-induced migration and violent conflict. Political Geography, 6., 656-673. http://doi.org/dvfnvv

Rudzitis, G. (1991): Migration, sense of place, and nonmetropolitan vitality. Urban Geography, 12., 80-88. http://doi.org/bdwz82

Sik E., Simonovits B. (2002): Migrációs potenciál Magyarországon 1993-2001. In: Kolosi T., Tóth I. Gy., Vukovich Gy. (szerk.): Társadalmi riport 2002. Tárki, Budapest, 207-219.

Sik E., Szeitl B. (2016): Migráció a mai Magyarországról. Educatio, 4, 546-557.

Vág A. (2010): A környezeti migráció okai. Tér és Társadalom, 3., 59-74. 